Pediat. Res. 8: 843-847 (1974)

Cerebellum

neonate

glucocorticoids thymidine kinase

\title{
Glucocorticoid Effect upon Thymidine Kinase in the Developing Cerebellum
}

\author{
MORTON E. WEICHSEL, JR. \\ Department of Human Development, College of Human Medicine, Michigan State University, East Lansing, Michigan, USA
}

\section{Extract}

Forty-nine litters of eight Sprague-Dawley rat pups were divided into four pups treated with $0.6 \mathrm{mg}$ hydrocortisone acetate on the day of birth and four littermate controls. The mean body weight, cerebellar weight, and cerebellar DNA were significantly depressed in treated pups by 3 days of age, with all three of these measurements of growth increasing in rate around 9 days of age, but remaining well below control values throughout 15 days of age. Body weight and cerebellar DNA were maximally depressed at age 12 days $(37.7 \%$ and $46.6 \%$ of control values, respectively), and cerebellar wet weight was maximally depressed to $51.5 \%$ of the control value at 9 days of age. The activity of thymidine kinase, a salvage pathway enzyme for pyrimidine biosynthesis, was found to be depressed to $80.2 \%$ and $74.1 \%$ of the control value at 3 and 6 days of age, respectively and elevated to $134 \%$ and $158 \%$ over control values at ages 12 and 15 days. The depression of thymidine kinase activity by hydrocortisone at ages 3 and 6 days followed by the overshoot of enzyme activity after steroid-induced growth suppression had subsided suggests that the thymidine kinase may be considered as having an essential regulatory function in the rate of DNA synthesis in developing brain.

\section{Speculation}

Extrapolation of these hormone-enzyme relations in developing rat cerebellum to the clinical use of glucocorticoids in acceleration of lung maturation in human premature infants suggests the possibility that concomitant effects of the steroid may be detrimental to the development of brain areas which undergo cell replication at the time the drug is administered.

Glucocorticosteroids have been used therapeutically for the last few years in diseases of early childhood including myoclonic seizures of childhood (9) and hypoglycemia (22). More recently, glucocorticoids have been used in animal experimentation in studies on maturation of the lung in lambs and rabbits. Liggins and Howie (18) showed that when labor can be delayed at least $24 \mathrm{hr}$ in unplanned deliveries of infants under 32 weeks gestation, infusion of $\beta$-methasone into the mother can prevent respiratory distress syndrome in the infant. These studies, which reflect the ability of glucocorticoids to accelerate lung maturation and prevent the consequences of surfactant deficiency, will undoubtedly lead to a greater volume of clinical experimentation regarding the use of glucocorticoids in mothers when premature delivery threatens. Although these recent clinical studies appear promising, little attention has been paid to possible deleterious effects of steroids on fetal organs other than the lung. Avery (4) has pointed out the possibility of permanent neurologic damage as a consequence of steroid therapy in the developing fetus, but more recently described profound effects of glucocorticoids upon brain development have not heretofore been emphasized in the pediatric literature. The studies of Balázs and Cotterrell (5) and Cotterrell et al. (12) on the effects of corticosteroids on the maturation of rat brain have laid the foundation for further studies of the developmental biochemistry of the brain under such potentially adverse endocrinologic conditions. It is the purpose of this paper to present the effect of glucocorticoids on the activity of thymidine kinase, an enzyme critical to the biosynthesis of pyrimidine nucleotides and DNA, in developing rat cerebellum, as further evidence supporting the possibility that glucocorticoids may have undesirable effects upon the developing human nervous system.

\section{MATERIALS AND METHODS}

Sprague-Dawley rats were used in the study (33). All pups were products of second pregnancies. Litters were reduced to a total of eight pups per dam without regard to sex. Four pups from each litter were treated with $0.6 \mathrm{mg}$ hydrocortisone acetate (Cortef acetate) (34) subcutaneously on the day of birth $($ day 0$)$ and the remaining four pups were given an equal amount $(50 \mu 1)$ of saline solution. Mortality of treated animals increased with age and was around $50 \%$ by age 15 days. Many were cannibalized before appearing sick. Dams were fed Wayne Lab Blox rat chow (35) and all animals were housed at $22^{\circ}$. All pups were numbered and weighed daily. Animals were active and suckled vigorously. Any animal appearing sick was not used. No special precautions were taken to prevent infection.

Pups from individual litters were killed at 3-day age intervals by decapitation. Brains were immediately removed and each cerebellum was weighed and homogenized in ice-cold homogenizing media with 20 up and down movements of the plunger of the homogenizer. At age 3 days, four control cerebella and four cerebella from treated animals were pooled to provide one experimental data point. At age 6 days it was necessary to pool two cerebella from treated animals. At all other ages, data points were derived from single cerebella. Homogenates were centrifuged at $35,000 \times g$ at $5^{\circ}$ for $20 \mathrm{~min}$ (36). The developmental curve for thymidine kinase was performed on the supernatant solution, using a $1 / 10-1 / 20(\mathrm{~W} / \mathrm{V})$ tissue homogenate.

Thymidine kinase was assayed by a procedure combining the method of Yamagami et al. (32) and Breitman (10) as modified for use in this laboratory in conjunction with other enzyme assays in rat brain tissue. 
Homogenizing medium consisted of sucrose $(0.25 \mathrm{M})$, potassium phosphate, $\mathrm{pH} 7.4(0.01 \mathrm{M}), \mathrm{MgSO}_{4}(0.015 \mathrm{M})$, ATP $(0.01 \mathrm{M})$, dithiothreitol $(1 \mathrm{mM})$, and glutamine $(3 \mathrm{mM})$.

The enzyme reaction mixture contained $0.2 \mathrm{ml}$ Tris- $\mathrm{HCl}$ buffer, pH $8(0.125 \mathrm{M}), 0.05 \mathrm{ml}$ ATP $(0.01 \mathrm{M}), 0.05 \mathrm{ml}^{3} \mathrm{H}-$ thymidine $(250 \mu \mathrm{Ci} / \mu \mathrm{mol})(37)$, and $0.2 \mathrm{ml}$ tissue homogenate supernatant. Final volume was $0.5 \mathrm{ml}$ with concentrations of $0.05 \mathrm{M}$ Tris- $\mathrm{HCl}$ buffer, $5 \mathrm{mM}$ ATP, $6 \mathrm{mM}$ magnesium sulfate, and $20 \mu \mathrm{M}\left({ }^{3} \mathrm{H}\right)$ thymidine.

Tubes were incubated at $37^{\circ}$ for $10 \mathrm{~min}$, and the reaction stopped by heating at $100^{\circ}$ for $3 \mathrm{~min}$. Tubes were then centrifuged at $4,000 \mathrm{rpm}$ for $15 \mathrm{~min}$ and supernatant aliquots of $0.1 \mathrm{ml}$, were placed on Whatman no. DE-81 discs. Discs were washed twice with $10-\mathrm{ml}$ aliquots of ammonium formate $(0.001 \mathrm{~N})$, distilled water, and with one $10-\mathrm{ml}$ aliquot of absolute ethanol. After drying the discs were placed in a counting vial with $10 \mathrm{ml}$ of Beckman Ready-Solv solution VI. Radioactivity was measured in a scintillation spectrometer (38).

Protein was determined on samples of supernatant solution, using the Oyama and Eagle modification (21) of the method of Lowry (19).

DNA was determined on samples of crude tissue homogenate using the modification by Giles and Myers (15) of the method of Burton (11).

Statistical analysis was applied to data points at each of the five ages of postnatal development by use of paired $t$ tests and confidence limits. In the $t$ test the mean data values from control animals and from treated animals were compared for the number of experimental litters used at each age. The number of experimental litters varied from 7 at age 3 days to 14 at age 6 days. For calculation of confidence limits, all values for pooled or single tissue samples in control and treated animals at each age were used. Number of values in control animals ranged from 7 at age 3 days to 24 at age 12 days and in treated animals ranged from 7 at age 3 days to 22 at age 12 days.

\section{RESULTS}

All data are presented in tabular form in Table 1. Figure 1 shows the effect of hydrocortisone injection at birth upon the body weights of rat pups through 15 days of extrauterine age. The mean body weight of treated pups is significantly below that of littermate controls by 3 days of age, and there is very little somatic growth until around 9 days of age. Around that time the animals appear to break through the influence of steroids and exhibit weight gain at a rate close to that of the controls. Maximum difference between controls and treated animals occurred at 12 days of age where the mean weight of treated animals was $37.7 \%$ of the controls.

Cerebellar wet weight was significantly reduced by 3 days of age in treated animals (Figure 2) and was maximally depressed at $51.5 \%$ of the control values by age 9 days.

Figure 3 shows the effect of hydrocortisone on cerebellar DNA (cell number). DNA was significantly depressed by paired $t$ test in the cerebella of treated animals by 3 days of age, and continued to be markedly below that of controls at all experimental ages. The maximum deficit occurred at age 12 days where cerebellar DNA was $46.6 \%$ of the control value but, as in Figure 1, the rate of DNA synthesis appeared to increase around the 9th day of life.

The developmental curve for thymidine kinase activity in control animals is compared with that for treated animals in Figure 4. Mean DNA values for the experimental and control animals in each age group are represented by bars at the appropriate age. The developmental curve for thymidine kinase in control animals peaks at age 6 days and activity of

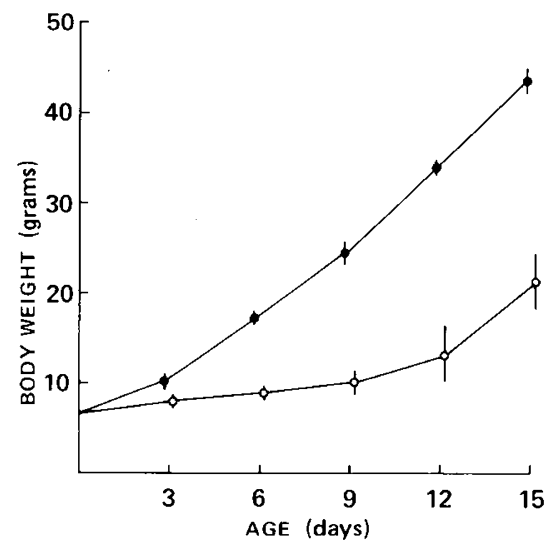

Fig. 1. Developmental curves for body weight of rat pups treated with $0.6 \mathrm{mg}$ hydrocortisone at birth $(\circ-\circ)$ and body weight of littermate controls $(\bullet-\bullet)$. Vertical bars represent confidence limits $(P$ $<0.05$ ).

Table 1. Measurements of development in cortisol-treated pups and controls ${ }^{1}$

\begin{tabular}{|c|c|c|c|c|c|}
\hline Age & $\begin{array}{l}\text { Body } \\
\text { wt, g }\end{array}$ & $\begin{array}{l}\text { Cerebellar } \\
\text { wet wt, mg }\end{array}$ & $\begin{array}{c}\text { Cerebellar } \\
\text { DNA, } \\
\mu \mathrm{g} / \text { cerebellum }\end{array}$ & $\begin{array}{c}\text { Cerebellar } \\
\text { TK activity, } \\
\mathrm{pmol} / \mathrm{min} / \mathrm{mg} \text { protein }\end{array}$ & $\begin{array}{l}\text { Cerebellar } \\
\Upsilon \mathrm{TK} \text { activity, } \\
\mathrm{m} \mu \mathrm{mol} / \mathrm{min} / \mu \mathrm{g} \text { DNA }\end{array}$ \\
\hline 3-day control & (28) $10.1 \pm 0.3^{2}$ & (28) $22.7 \pm 0.9^{2}$ & (7) $109.6 \pm 8.7^{2}$ & (7) $45.4 \pm 1.4^{2}$ & (7) $270.8 \pm 11.1^{2}$ \\
\hline 3-day treated & (27) $8.0 \pm 0.2^{2}$ & (27) $19.3 \pm 0.7^{2}$ & (7) $92.7 \pm 5.8^{2}$ & (7) $36.4 \pm 1.6^{2}$ & (7) $223.0 \pm 14.3^{2}$ \\
\hline 6-day control & (32) $17.2 \pm 0.4^{2}$ & (32) $47.4 \pm 1.2^{2}$ & (20) $278.1 \pm 14.0^{2}$ & (21) $53.7 \pm 1.0^{2}$ & (20) $301.6 \pm 19.7^{2}$ \\
\hline 6-day treated & (38) $8.9 \pm 0.3^{2}$ & (38) $28.2 \pm 1.0^{2}$ & (19) $162.8 \pm 8.8^{2}$ & (21) $39.5 \pm 1.7^{2}$ & (20) $225.4 \pm 13.0^{2}$ \\
\hline 9-day control & (16) $24.4 \pm 0.6^{2}$ & (16) $84.1 \pm 3.0^{2}$ & (16) $626.6 \pm 26.4^{2}$ & (16) $39.1 \pm 1.5$ & (16) $235.7 \pm 16.7$ \\
\hline 9-day treated & (15) $10.0 \pm 0.6^{2}$ & (15) $43.3 \pm 3.2^{2}$ & (15) $320.8 \pm 20.5^{2}$ & (15) $35.2 \pm 1.2$ & (15) $221.0 \pm 15.0$ \\
\hline 12-day control & (29) $34.1 \pm 0.4^{2}$ & (29) $120.8 \pm 2.0^{2}$ & (28) $957.6 \pm 13.3^{2}$ & (29) $15.3 \pm 0.9^{2}$ & (28) $59.0 \pm 3.8$ \\
\hline 12-day treated & (22) $13.2 \pm 1.5^{2}$ & (22) $63.0 \pm 5.4^{2}$ & (22) $446.2 \pm 27.0^{2}$ & (22) $20.5 \pm 1.7^{2}$ & (22) $84.2 \pm 5.8$ \\
\hline 15-day control & (31) $43.6 \pm 0.7^{2}$ & (31) $150.6 \pm 1.9^{2}$ & (31) $1112.8 \pm 13.8^{2}$ & (31) $5.2 \pm 0.3^{2}$ & (31) $22.3 \pm 1.3^{2}$ \\
\hline 15-day treated & (19) $21.4 \pm 6.6^{2}$ & (19) $93.4 \pm 6.6^{2}$ & (19) $676.7 \pm 25.1^{2}$ & (19) $9.0 \pm 0.6^{2}$ & (19) $37.3 \pm 3.8^{2}$ \\
\hline
\end{tabular}

1 TK: thymidine kinase. Mean value \pm SEM. The number of values for each calculation (all samples at 3 day and some samples at 6 day were pooled for DNA and thymidine kinase activity calculations) are given in parentheses.

${ }^{2}$ Indicates statistical significance between treated and control groups by paired $t$ test $(P<.05)$ 


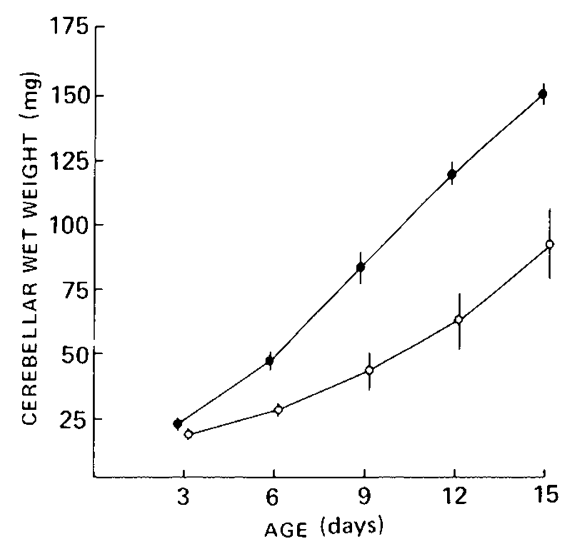

Fig. 2. Developmental curves for cerebellar wet weight of rat pups treated with $0.6 \mathrm{mg}$ hydrocortisone at birth $(\mathrm{O}-\mathrm{O})$ and cerebellar wet weights of littermate controls $(\bullet-\bullet)$. Vertical bars represent confidence limits $(P<0.05)$.

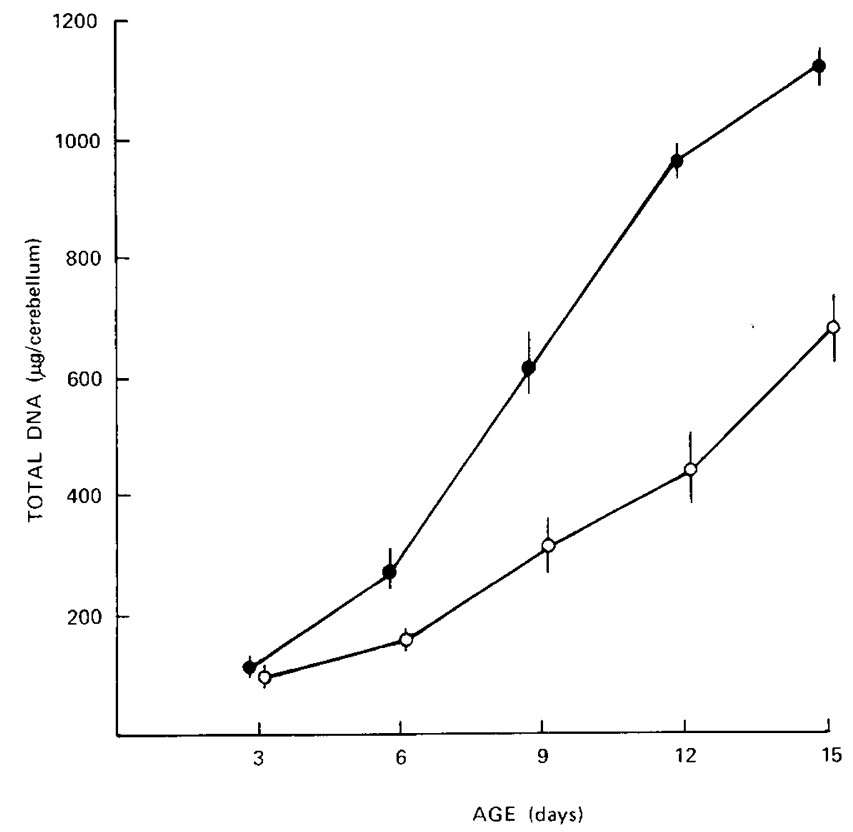

Fig. 3. Developmental curves for total cerebellar DNA in rat pups treated with $0.6 \mathrm{mg}$ hydrocortisone at birth $\left(\mathrm{O}_{-} \mathrm{O}\right)$ and total cerebellar DNA of littermate controls $(\bullet-\bullet)$. Vertical bars represent confidence limits $(P<0.05)$.

the enzyme declines rapidly thereafter. Under conditions of the assay, activity of thymidine kinase could not be detected by 18 days of extrauterine life. Mean values for thymidine kinase activity in treated animals when expressed as activity per milligram of protein are significantly less than values in control animals at both 3 and 6 days of extrauterine life, the values being $80.2 \%$ and $74.1 \%$ of normal, respectively. At both 12 and 15 days of life the activity of thymidine kinase in treated littermates was greater than that in controls with values being $134 \%$ and $158 \%$ of normal, respectively. Crossing over of the two curves occurred at around 9 days of age. The differences described were significant at ages $3,6,12$, and 15 days by paired $t$ test $(P<0.05)$, and at ages 3,6 , and 15 days by confidence limits $(P<0.05)$. In addition, Table 1 contains values for thymidine kinase activity, expressed as enzyme activity per microgram of DNA. These data show significant differences similar to those noted when activity is expressed on the basis of milligrams of supernatant protein.

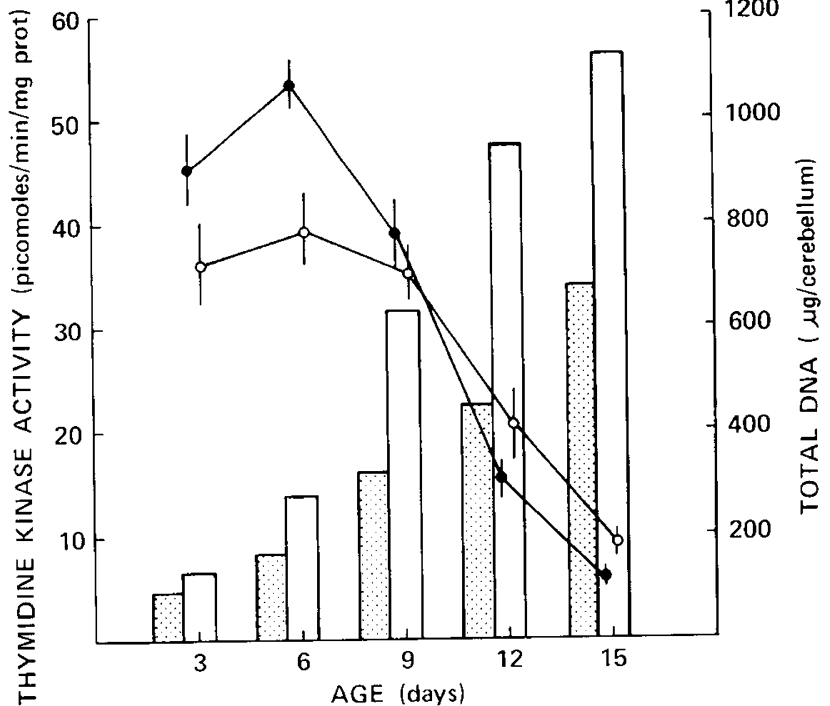

Fig. 4. Activity of thymidine kinase in cerebellum of developing rat pups treated with $0.6 \mathrm{mg}$ hydrocortisone at birth $(0-0)$ and in littermate controls (•-). The enzyme activity is reported as picomoles per minute per milligram protein, and is compared with the total DNA content in cerebellum of treated animals (stippled bars) and of littermate controls (open bars). Thymidine kinase was assayed as described in Materials and Methods. Vertical bars represent confidence limits $(P<0.05)$.

\section{DISCUSSION}

Cortisol administration in the newborn rat was noted by Shapiro (25) to affect body weight, brain chemistry, and behavior, as well as to delay cerebral ontogeny. Cotterrell et al. (12) were able to produce retarded body growth in rats by using a smaller initial dose of cortisol injected at birth, and were able to obtain a more lasting retardation of growth by using supplementary doses of cortisol during the succeeding 3 days of life. Treated rats in our experiments received a single dose of $0.6 \mathrm{mg}$ cortisol, which served the purpose of avoiding the high mortality reported by Shapiro et al. (25), while causing severe growth retardation for at least 6 days of life and allowing the treated animals to resume a growth rate closer to that of the controls by around 9 days of extrauterine age when the cerebellum is still undergoing active cell division.

Altman $(1,2)$, using tritiated thymidine, demonstrated a very high rate of cellular multiplication in the external granular layer of the rat cerebellum that persists for 2 weeks after birth. Subsequently, by the end of the $3 \mathrm{rd}$ week of extrauterine life, the external granular layer has disappeared and most of these cells have migrated to deeper layers of the cerebellum to enter a phase of further differentiation. During this first 3-week period there is as high as an eightfold increase in cerebellar DNA $(14,29)$, which is generally considered to be proportional to cell number since DNA is constant within any diploid cell in a given species (7). This rapid accumulation of cerebellar DNA, which represents a large proportion of cerebellar microneuron precursors, affords an ideal experimental model for other brain areas or other organs upon which to test hypotheses relating to the effect of environmental stimuli on cell proliferation and biochemistry relating to DNA biosynthesis.

The retardation in body growth in our treated animals (Fig. 1) was similar to that described by Cotterrell et al. (12) and appears to depend on the dosage schedule chosen for the particular experiment. Cerebellar wet weight (Fig. 2) in the treated animals is markedly depressed compared with controls by 6 days of age, and DNA values in cerebellums of control 
and treated animals are significantly different by 3 days of age as determined by paired $t$ test (Fig. 3). Although the developmental curve for DNA in the control animals is of similar shape as that reported previously, the total cerebellar DNA at 9 days and later is less than that observed previously by other laboratories $(29,30)$, which suggests that there are multiple variables involved in such biologic measurements. The severe depression of cerebellar DNA synthesis in treated animals through approximately 9 days of age followed by an increase in rate of synthesis provides an excellent system for study of key enzymes in metabolic pathways which lead to nucleic acid synthesis.

Pyrimidines may be incorporated into nucleic acids by two pathways, the de novo pyrimidine biosynthetic pathway, which utilizes the simple substrates $\mathrm{CO}_{2}$, ATP, and glutamine, and salvage pathways by which preformed nucleosides are phosphylated by kinase enzymes. Thymidine kinase, a salvage pathway enzyme for pyrimidine biosynthesis, was the subject of this study because of the relative large incorporation of radioactively labeled thymidine into rat cerebellum during the period of most rapid cell replication, and because of the inhibition of that incorporation in cortisol-treated animals (12).

Our developmental curve for thymidine kinase in normal cerebellum (Fig. 4) peaks at 6 days of extrauterine age and closely parallels the cerebellar developmental curves described by Yamagami et al. (32) and Sung (26). The time of maximum thymidine kinase activity is thus much the same as that of the highest incorporation of labeled thymidine into brain DNA (20). The significant reduction in thymidine kinase activity at 3 and 6 days of age in cortisol-treated animals (Fig. 4) suggests that glucocorticoids may have a selective effect on this enzyme at a time just before and during the peak activity of the enzyme. This depression of thymidine kinase activity, expressed on the basis of enzyme activity per milligram of supernatant protein or enzyme activity per microgram of DNA, occurs in a situation in which the cerebellar wet weight (Fig. 2) is significantly below that of controls, but protein and RNA levels per cell have been shown to be unaffected (12). Attempts to show a similar depression in thymidine kinase activity at 6 days of age in rat pups subjected to exogenous protein-calorie undernutrition were unsuccessful. Comparison of the most undernourished animals in litters of 16 pups to control animals from normal size litters revealed no significant differences in cerebellar thymidine kinase activity (54.72 \pm $2.13 \mathrm{SEM}$ versus $54.30 \pm 2.82 \mathrm{SEM} \mathrm{pmol} / \mathrm{min} / \mathrm{mg}$ protein, respectively). Experimentally, using the large litter method for production of undernutrition, it proved impossible to maintain rat pups at body weights as low as those recorded in the steroid-treated animals.

The developmental curve for cerebellar thymidine kinase in cortisol-treated rats also reveals that during the period following that in which the glucocorticoids exerted maximum influence on body and cerebellar weight, the thy midine kinase activity in treated animals increased to levels significantly higher than littermate controls. This elevation of enzyme activity in treated animals at 12 and 15 days of age occurred during a period when the rate of cerebellar DNA accumulation approached that of control animals. It is possible that growth at these ages reflected improved nutrition because of increasing mortality and reduction in litter size (dead animals were not replaced); however, both control as well as treated pups in each litter were subject to the same influences. Although ultimate cerebellar DNA in treated animals does not ever reach control values (12), the apparent attempt at "catch-up" growth is thus reflected in increased thymidine kinase activity and is consistent with the findings of Cotterrell et al. (12), which show that there is an accelerated mitotic activity by radioactive thymidine incorporation in cerebellums of cortisol-treated animals at age 20 days. In another sense, the developmental curve for cerebellar thymidine kinase in cortisol-treated animals (Fig. 4) may represent a shift in the developmental spectrum of activity for this enzyme, although the age of peak activity was not shown by statistical means to be shifted when age intervals as great as 3 days were used.

Although control of DNA synthesis may involve many factors, our findings are consistent with the concept of Bollum and Potter (8) and Bianchi et al. (6) that thymidine kinase may be considered as the essential regulatory control enzyme in the rate of DNA synthesis as demonstrated in regenerating rat liver, and that there may be a similar mechanism during brain development $(26,32)$. Pratt and Aranow (23) observed that, in a study of cultured fibroblasts, inhibition of thy midine incorporation by cortisone may result from inhibition of DNA polymerase. Inhibition of liver DNA polymerase was also demonstrated by administration of cortisone to young rats (16). Alternatively, studies by Kaneko and LePage (17), using Ehrlich ascites cells, revealed only slight inhibition of DNA polymerase and marked inhibition of thymidine kinase after pretreatment with cortisone, which points to a possible regulatory function for thymidine kinase in DNA synthesis.

The means by which steroids regulate the synthesis of certain proteins is not known, and a number of mechanisms have been postulated. All steroids are known to stimulate the synthesis of specific proteins, but it has proven difficult to determine which proteins are directly affected and which could be secondarily affected by a mechanism such as the modulation of RNA, DNA, or protein synthesis, or in limiting the rate of metabolic reactions (27). Studies with inhibitors of macromolecule synthesis suggest that specific enzyme inductions may be involved in the catabolic as well as the anabolic effects of steroids. Inhibitory effects of glucocorticoids on enzymes are much less frequent than the stimulatory effects, and thus for the present time the mechanism underlying the depression of thymidine kinase by glucocorticoids as well as the reversal noted during catch-up growth must remain open to speculation.

Cell division in the human brain is very active until after 1 year of age. Human cerebellar DNA content increases at least fourfold between birth and 1 year of age (31), and the cerebellar external granular layer of cells is present long after that. This layer gives rise largely to neurons in the rat, mouse, cat, dog, chick, and probably in man (28), and attains its maximum cell number in man at some stage after birth (24). Cerebral DNA in the human neonate increases threefold in the 1st year of life (31), but there is less evidence for postnatal neuronal mitosis. Dobbing (13) feels that postnatal increase in DNA in the human cerebrum probably represents the proliferation of glial cells. Hippocampal neuronal mitosis occurs postnatally, however, in the guinea pig brain, which is more mature at birth than the human brain (3); this suggests that similar postnatal mitosis may occur in the human hippocampus. Thus the evidence supports the likelihood that neuronal as well as glial cell replication continues postnatally in the human infant, and that such dividing cells may be vulnerable in varying degrees to the same stimuli which impair brain cell proliferation in animal models.

The trend toward experimentation in humans by the administration of glucocorticoids to mothers threatening premature delivery will undoubtedly lead towards trials of different types and amounts of glucocorticoids. These steroids cross the placenta to potentially enter the circulation of the fetus, and hopefully exert the desired effect on target tissues in the lung in order to induce surfactant, reduce the incidence of respiratory distress syndrome in premature infants, and thus reduce perinatal morbidity and mortality secondary to prematurity.

Because of the fairly rapid effects of corticoids upon pulmonary biochemistry and physiology as demonstrated with the use of $\beta$-methasone (18), it is reasonable to expect that 
other transplancental effects of glucocorticoids on enzyme systems might be manifest during the same period of time. Glucocorticoids may have an effect on brain regions which are still in the phase of cell replication and may have a specific effect on thymidine kinase or other enzymes responsible for nucleic acid biosynthesis and nerve cell replication. Thus the data presented suggest that in spite of the salutary effects of corticoids on some target tissues, consideration must be given to possible hazardous effects, however subtle, upon central nervous system development and appropriate follow-up studies on treated infants should be devised to identify any such undesirable effects.

\section{SUMMARY}

The developmental curve for thymidine kinase in cerebellums of hydrocortisone-treated rat pups is significantly depressed compared with that from littermate controls at 3 and 6 days of postnatal age. The decrease in enzyme activity in treated animals correlates with the depression of cerebellar DNA synthesis. Activity of thymidine kinase is greater in cerebellums of treated animals that controls at ages 12 and 15 days, when the steroid effect on growth has subsided, corresponding in time to an increase in the rate of cerebellar DNA synthesis and suggesting a catch-up effect. Thymidine kinase may have a regulatory function in cerebellar DNA synthesis. The suppression of cerebellar thymidine kinase activity by glucocorticoids is presented as a model for considering the relation of various hormones to cellular development in a variety of tissues and organs. Specifically, this model emphasizes the potential hazards to brain cell development when glucocorticoids are used to accelerate lung maturation during or before spontaneous delivery of premature infants.

\section{REFERENCES AND NOTES}

1. Altman, J.: Autoradiographic and histologic studies of postnatal neurogenesis. II. A longitudinal investigation of the kinetics, migration, and transformation of cells incorporating tritiated thymidine in infant rats, with special reference to postnatal neurogenesis in some brain regions. J. Comp. Neurol., 128: 431 (1966).

2. Altman, J.: Autoradiographic and histological studies of postnatal neurogenesis. III. Dating the time of production and onset of differentiation of cerebellar microneurons in rats. J. Comp. Neurol., 136: 269 (1969).

3. Altman, J., and Das, G. D.: Postnatal neurogenesis in the guinea pig. Nature, 214: 1098 (1967).

4. Avery, M. E.: Prevention of hyaline membrane disease: Commentary. Pediatrics, 50:513 (1972).

5. Balázs, R., and Cotterrell, M.: Effect of hormonal state on cell number and functional maturation of the brain. Nature, 236: 348 (1972).

6. Bianchi, P. A., Crathorn, A. R., and Shooter, K. V.: Thymidine kinases and deoxyribonucleic acid synthesis in normal and regenerating rat liver. Biochim. Biophys. Acta, 61: 728 (1962).

7. Boivin, A., Vendrely, R., and Vendrely, C.: L'acide de'soxyribonucleique du noyau celluaire de'positaire des caracteres hereditaires; arguments d'ordre analytique. C. R. Acad. Sci. Paris, 226: 1061 (1948).

8. Bollum, F. J., and Potter, V. R.: Nucleic acid metabolism in regenerating rat liver VI. Soluble enzymes which convert thymidine to thymidine phosphates and DNA. Cancer Res., 19: $561,(1959)$.

9. Bray, P. F.: Neurology in Pediatrics, p. 28 (Year Book Publishers, Inc., 1969).

10. Breitman, T. R.: The feedback inhibition of thymidine kinase. Biochim. Biophys. Acta, 67: 153 (1963).

11. Burton, K.: A study of the conditions and mechanisms of the dephenylamine reaction for the colorimetric estimation of deoxyribonucleic acid. Biochem J., 62: 315 (1956).

12. Cotterrell, M., Balaźs, R., and Johnson, A. L.: Effects of corticosteroids on the biochemical maturation of rat brain: Postnatal cell formation. J. Neurochem., 19:2151 (1972).

13. Dobbing, J.: Undernutrition and the developing brain. Amer. J. Dis. Child., 120: 411 (1970).

14. Fish, I., and Winick, M.: Effect of malnutrition on regional growth of the developing rat brain. Expl. Neurol., 25: 534 (1969).

15. Giles, K. W., and Myers, A.: An improved dephenylamine method for the estimation of deoxyribonucleic acid. Nature, 206: 93 (1965).

16. Henderson, I. G., and Loeb, J. W.: Fall in liver DNA polymerase activity in cortisone treated rats. Nature, 228: $556(1970)$.

17. Kaneko, T., and LePage, G. A.: Inhibition of thymidine kinase by cortisone. Proc. Soc. Expl. Biol. Med., 133: 229 (1970).

18. Liggins, G. C., and Howie, R. N.: A controlled trial of antepartum glucocorticoid treatment for prevention of the respiratory distress syndrome in premature infants. Pediatrics, 50: 515 (1972).

19. Lowry, O. H., Rosebrough, N. J., Farr, A. L., and Randall, R. J.: Protein measurement with the Folin phenol reagent. J. Biol. Chem., 193:,265 (1951).

20. Mori, K., Yamagami, S., and Kawakita, Y.: Thymidine metabolism and deoxyribonucleic acid synthesis in the developing rat brain. J. Neurochem., 17: 835 (1970).

21. Oyama, V. I., and Eagle, H.: Measurement of cell growth in tissue culture with a phenol reagent (Folin-Ciocalteau). Proc. Soc. Exp. Biol. Med., 91: 305 (1956).

22. Pagliara, A. S., Karl, I. E., Haymond, M., and Kipnis, D. M.: Hy poglycemia in infancy and childhood. Part I. J. Pediat., 82: 365 (1973).

23. Pratt, W. B., and Aranow, L.: The effect of glucocorticoids on protein and nucleic acid synthesis in mouse fibroblasts growing in vitro. J. Biol. Chem., 241: 5244 (1966).

24. Rakic, P., and Sidman, R. L.: Histogenesis of cortical layers in human cerebellum, particularly the lamina dissecans. J. Comp. Neurol., 139: 473 (1970).

25. Shapiro, S.: Some physiological, biochemical, and behavioral consequences of neonatal hormone administration: Cortisol and thyroxine. Gen. Comp. Endocrinol., 10:214 (1968)

26. Sung, S. C.: Thymidine kinase in the developing rat brain. Brain Res., 35: 268 (1971)

27. Tomkins, G. M., and Gelehrter, T. D.: The present status of genetic regulation by hormones. In: G. Litwack: Biochemical Actions of Hormones, Vol. II, p. 1 (Academic Press, New York, 1972).

28. Wasterlain, C. and Plum, F.: Vulnerability of developing brain to electro-convulsive seizures. Arch. Neurol., 29: 38 (1973).

29. Weichsel, M. E., Jr., Hoogenraad, N. J., Levine, R. L., and Kretchmer, N.: Pyrimidine biosynthesis during development of the rat cerebellum. Pediat. Res. 6:682 (1972)

30. Winick, M.: Nutrition and nerve cell growth. Fed. Proc., 29: 1510 (1970).

31. Winick, M., Rosso, P., and Waterlow, J.: Cellular growth of cerebrum, cerebellum, and brain stem in normal and marasmic children. Exp. Neurol., 26: 393 (1970).

32. Yamagami, S., Mori, K., and Kawakita, Y.: Changes of thymidine kinase in the developing rat brain. J. Neurochem., 19: 369 (1972).

33. Spartan Farms, Haslett, Mich.

34. The Upjohn Company, Kalamazoo, Mich.

35. Allied Mills, Inc., Chicago, Ill.

36. RC-2-B centrifuge, Ivan Sorvall, Inc., Norwalk, Conn.

37. Amersham/Searle, Arlington Heights, Ill.

38. Beckman liquid scintillation counter model LS-100, Beckman Instruments, Palo Alto, Calif.

39. The author gratefully acknowledges the technical assistance of $M$ iss Malonnie Kinnison and Mrs. Lila Dawson, and critical review of the manuscript by William B. Weil, Jr., M.D.

40. This research was supported by Michigan State University General Research Support Grants 71-0993 and 71-0903, and by National Institutes of Health Grant no. HD-07275-01 from the United States Public Health Service.

41. Requests for reprints should be addressed to: M. E. Weichsel, Jr., M.D., Department of Human Development, College of Human Medicine, Michigan State University, East Lansing, Mich. 48824 (USA).

42. Accepted for publication June 12, 1974. 